\title{
ROOT CAUSES OF RURAL DECLINE IN ECONOMIC WELL-BEING IN FINLAND
}

\author{
Olli Lehtonen ${ }^{1}$, Markku Tykkyläinen ${ }^{2}$, Olli Voutilainen ${ }^{3}$
}

Received 8 August 2011; Accepted 23 March 2012

\begin{abstract}
This paper analyses how dependence on primary production, distance, climatic conditions and the intensity of land use bring about variations in economic well-being in rural areas. The conventional interpretation in Finland often concludes that economic well-being declines as dependence on primary production increases. The potential oversimplification implied by this statement was studied by testing the explanatory power of distance from the nearest large city, effective temperature sum and the proportion of fields in a comparative setting. The results revealed that economic well-being in rural Finland is best explained by the effective temperature sum, followed by distance, dependence on primary production and the proportion of fields. The only element of well-being which is determined chiefly by dependence on primary production is educational capital, causing a bottleneck preventing rural areas from becoming competitive and hence attractive to new knowledge-intensive industries. These results cast light on the spatial conditions under which the current economic evolution towards a service and knowledge society is taking place and on the spatial manifestations of remnant economic structures in disadvantageous locations.
\end{abstract}

Keywords: Well-being, rural development, quantitative methods, Finland

Yhteenveto: Tässä artikkelissa tutkimme, kuinka riippuvuus alkutuotannosta, etäisyydestä, ilmastosta ja maankäytöstä on yhteydessä maaseutualueiden taloudelliseen hyvinvointiin Suomessa. Tutkimuksemme pohjautuu perinteiseen näkemykseen siitä, että taloudellinen hyvinvointi vähentyy alkutuotantoriippuvuuden lisääntyessä. Tätä oletusta tutkimme eksploratiivisesti testaamalla kolmen selittävän muuttujan selitysvoimaa suhteessa alkutuotantoriippuvuuteen. Käytetyt selittävät muuttujat olivat alueen etäisyys lähimpään suureen kaupunkiin, tehoisa lämpösumma ja peltopinta-alan osuus alueen pinta-alasta. Tulokset paljastavat, että taloudellinen hyvinvointi maaseudulla on parhaiten selitetty ilmastoa kuvaavalla tehokkaalla lämpösummalla, toiseksi parhaiten alueen sijainnilla eli etäisyydellä suureen kaupunkiin, ja vasta kolmanneksi parhaiten alkutuotantoriippuvuudella. Heikoin selittäjä hyvinvoinnille oli peltopinta-alan osuus maapinta-alasta. Ainoa hyvinvoinnin

\footnotetext{
1 Olli Lehtonen, University of Eastern Finland Department of Geographical and Historical Studies, P.O. Box 111 80101 Joensuu, e-mail: olli.lehtonen@uef.fi

${ }^{2}$ Markku Tykkyläinen University of Eastern Finland Department of Geographical and Historical Studies P.O. Box 111 80101 Joensuu, e-mail: markku.tykkylainen@uef.fi

${ }^{3}$ Olli Voutilainen MTT Economic Research Agrifood Research Finland Helsinki
} 
osatekijä, joka määrittyi selkeästi riippuvuudesta alkutuotantoon, oli koulutuksellinen pääoma. Tuloksemme valottavat spatiaalisia olosuhteita, joissa talouden evoluutio kohti palvelu- ja tietoyhteiskuntaa tapahtuu, ja paljastavat epäsuotuisten sijaintien merkityksen taloudellisessa hyvinvoinnissa.

Avainsanat: Hyvinvointi, maaseudun kehitys, kvantitatiiviset menetelmät, Suomi

\section{Introduction}

The role of agriculture and forestry in employment has consistently diminished in rural Europe over recent decades. In the boreal zone, labour productivity has increased in the forest sector, reducing the amount of labour required in forestry and the forest industries, while efficiency has increased in agriculture. For rural Finland, this has meant that unemployment has remained high, reflecting structural problems and a lack of opportunities for economic diversification. Sparsely populated areas in the north of the European Union are examples of the areas which face high unemployment and relative low incomes (Gløersen et al. 2005). Rural Canada faces comparable problems (e.g. Freudenburg \& Gramling 1994; Overdevest \& Green 1995; Stedman et al. 2004; Stedman et al. 2005; Patriquin et al. 2007). The decline in rural economies is normally said to be due to a combination of local factors such as a small, declining and ageing population, distant location, a weak infrastructure of communications and services, and industries that are in their mature stage (Markey et al. 2006). Many of these factors are really effects of rural decline and not its ultimate causes, which leads one to think that a wider, geographical research setting could give more valid results.

The reasons for rural decline are thought to depend very much on the rural economic structure and its dynamics. Less attention has been paid to the physical properties of given areas, the impacts of which on economic performance and economic well-being have mostly been recognized by comparing countries (Sachs \& Warner 1997a; 1997b; Gallup et al. 1999). Only a few papers such as Gløersen et al. (2005: 155-159) have addressed this issue in their interpretations of the reasons for rural decline. At the regional level, the transformation to a knowledge economy, that is urban-centric, is most problematic in rural areas which are heavily dependent on inadequate regional assets and human skills or generating new production (Kangasharju \& Pekkala 2004). As regional development and economic well-being are increasingly related to the utilization of knowledge in a few locations, we assume that the location of an area related to urban networks has a crucial impact on rural economic wellbeing. The physical attributes of a region that affect economic well-being may be accounted for by considering its climatic conditions and land use, the values of which vary or become transformed in the course of long-term development.

In this paper we set out to investigate how dependence on primary production, distance from urban centres and physical attributes affect the elements of economic well-being in Finnish rural areas at a micro-area level. That is, we propose to analyse the root causes of economic wellbeing and the significance of confounding factors in explaining its components and to visualize and test their respective impacts in a research setting that involves the consideration of three variables at a time. To our knowledge no research of this kind has previously been carried out at the postcode area level. We focus our analysis on rural Finland in 2003-4.

\section{Economic well-being, dependence on primary production, and geography}

Individuals, regions and countries strive for economic well-being, a concept that is associated with "being well, happy and prosperous" and clearly mirrors the satisfaction of human needs (van de Ven et al. 1999; Kainulainen et al. 2001; Karvonen \& Kauppinen 2009). One major issue when defining economic well-being as the satisfaction of human needs is what factors provide the means for generating economic well-being for individuals or for an area at large. For many, economic well-being stands for reasonable incomes, financial assets, employment and education (Stedman et al. 2004). Based on the literature and on Finnish empirical studies, we regard economic well-being as consisting of five dimensions of human life: incomes, education, 
net property and debts and the risk of becoming unemployed (e.g. Stedman et al. 2004: 221; Karvonen \& Rintala 2007; Karvonen \& Kauppinen 2009; Patriquin et al. 2007). The formation of this asset we will explain by dependence on primary production and geography existing in a rural setting.

As the central source of economic well-being, one common characteristic of rural areas is their reliance on resource-based production. Efforts to describe resource dependence in economic approaches have usually been based on employment and income statistics, in order to measure the proportion of economic activities linked to specific industries (Mekbeb et al. 2009: Stedman et al. 2004, 221; Patriquin et al. 2007). The most common way to capture dependence is to express it as employment in natural resource industries as a proportion of total employment (Stedman et al. 2004). Here, we therefore chose to use the proportion of employees in agriculture, forestry and fishing within the total number of employed persons by post code area as the indicator of dependence. The notion of dependence on primary production is somewhat narrower than the often used term resource dependence (ibid.), but it is better suited for our purposes.

Primary production dominance is traditionally associated with lower economic well-being, implying that the latter can be interpreted as indicating that the markets for production factors are unbalanced (Krugman 1991). Pressures to restructure exist, and the imbalance could be corrected by better spatial allocation of the factors of production. This may mean investments on-site, improving local competence, or migration, i.e., an overall balance in the spatial economy can be achieved in various ways. Papyrakis and Gerlagh (2007) compared regional economic growth rates in the United States and suggested that while abundant natural resource extraction should fuel growth in the early stages of development, reliance on natural resources for economic activity may reduce entrepreneurial activities and lessen the incentives for innovation and economic diversification. From the viewpoint of sectoral restructuring, rural decline is interpreted as being the outcome of recessive economic structures and their underlying causes.

The findings of earlier studies have often revealed the negative impacts of forestry dominance (dependence on logging) on economic well-being, such as high poverty rates and unemployment (Freudenburg \& Gramling 1994: Overdevest and Green 1995; Stedman et al. 2004; Stedman et al. 2005; Patriquin et al. 2007). Leake et al. (2006), for instance, found that forest dependence in Canadian communities had a significant positive correlation with the unemployment rate and an increase in the poverty of households over the period 19861996. As shown, economic structures correlate with poverty, but poor wages are only the top of the iceberg of the complex causes of poverty. Geographically marginal regions have tended to suffer most in Europe, as a result of more difficult natural conditions (Espon Project 2.1.3). In Finland, the structural change in agriculture has been most pronounced in the climatically colder and physically more hilly eastern rural areas, as it is here that the numbers of farms have decreased most during recent decades (Pyykkönen 2001). At the same time, agricultural production has become more capital-intensive, which has lowered the level of agricultural employment. Sub-regions based more on primary production had on average lower productivity and lower growth in productivity in the 1990s than regions relying more on other industries (Kangasharju \& Pekkala 2004).

At a time when economic growth is concentrated in the largest cities, geographically marginal regions have tended to suffer most in Europe due to their more problematic location, resource dependence and natural conditions (Terluin \& Post 2000; Espon Project 2010). In Finland, the growth of a new knowledge-based economy in large urban areas and adjacent rural areas has attracted labour from less productive sectors and areas (Castells \& Himanen 2002; Tervo 2009). Similarly, in Canada rural areas close to the largest cities have succeeded better than other rural areas in compensating for employment losses in the primary industries, as they have benefited from commuting to the regional cores (Partridge et al. 2007; Polèse \& Shearmur 2004). These studies suggest that the more peripheral a locality is, the more disadvantaged it will be, partially due to low population density and remote location. Thus, economic well-being occurs unevenly geographically, often as a result of core-periphery mechanisms, raising 
the question of the extent to which the level of economic well-being in an area is dependent on its position in spatial structures and on its natural conditions.

The poor development in rural economic well-being in Finland is undoubtedly dependent on natural and human spatial attributes, the values and cost effects of which are not equally distributed geographically. The reasons for poor economic performance may be a matter of distance, climate, land use or structural properties created by human agency. This still ambiguous interpretation leads us to study what are the root causes for rural decline.

\section{Hypotheses, explanatory variables and data}

\subsection{Research hypotheses}

In order to be able to investigate the impact of the less conventional spatial attributes, relative location and physical attributes, on economic well-being in rural areas when approaching the topic in an otherwise traditional way, we assume in the first hypothesis that the constituents of economic well-being at a postcode area level decline as dependence on primary production increases. We will use the results of this analysis later to analyse how causal this statement actually is. This line of reasoning is consistent with theories which explain the shift of employment and investments away from less profitable industries to more lucrative ones as compensations for the factors of production diminish (Krugman 1991). The first hypothesis can be investigated by means of bivariate correlation analysis.

Economic deregulation has taken place in Finland unveiling geographical differences and their impacts on the costs of production. Thus, we put the second hypothesis that the variation in rural economic well-being can be explained at least in part by the spatial variation in placespecific attributes related to climate, location and land rather than by dependence on primary production because they have an impact on the costs structures of production and subsequently on incomes. The place-bound cause of the decay in economic performance in peripheries is that profits fall and production pushes out from marginal lands leaving such areas available for less economic use. The more marginal an area is in terms of location and physical attributes, the less advantageous the cost structures will be for new production and living. There is much evidence that natural conditions, such as climate, soil, accessibility, have impact on industrial development, the level of income, settlement patterns and population development globally in the long term (Sachs \& Warner 1997a; 1997b; Gallup et al. 1999; Hill \& Gaddy 2003; Zhang et al. 2011), although many social and individual reasons influence locational decisions at a micro scale (Lundholm 2007; Tuhkunen 2007; Heleniak 2009; Partridge 2010). Our focus is on the first-mentioned structural spatial dependencies.

Some of the rural areas have gained better initial advantages on the strength of their spatial physical attributes than other areas, rendering them more successful and giving them a higher level of economic well-being. We postulate in that the impact of distance has been highlighted since the last urban-centric ICT-based period of economic growth, and we investigate the determinants of economic well-being in 2003-2004, when the most intense boom phase was over (Colecchia \& Schreyer 2002; Jalava \& Pohjola 2007). The empirical independent variables are distance of each rural postcode area from the nearest large city (over 100000 inhabitants), the local effective temperature sum (ETS) and the proportion of fields within the total surface area. We refer to these as spatial attributes, as they vary systematically in the geographical space for a particular physical or social reason. Our second hypothesis is supported by previous findings implying that distance from an urban environment is an important variable explaining development (e.g. Partridge et al. 2007; Partridge et al. 2008) and that the impact of the effective temperature sum on costs and production favours location in the temperate zone, and encourages industrial concerns to develop their activities there (Gallup et al 1999; Hill \& Gaddy 2003). The prevalence of fields evolved in response to regional variations in natural conditions with respect to fertile land and climate.

We assume in the third hypothesis, based on the existing literature on the rapid spatial concentration of economic activities and urbanization (Mukkala 2004; Cutrini 2010; Andaluz et al. 2002), that the impact of relative location is higher than the impact of climate (ETS) and the proportion of fields on the economic well-being of rural areas. This hypothesis arises from 
the second one, because it is unclear which are the underlying processes behind dependence on primary production which seem to lead to low economic well-being and spatial shifts in productive capital. This hypothesis is investigated by means of the permutation test described below.

To test the second hypothesis, non-parametric regression analysis is employed to create surfaces which show the impact of the spatial attributes and dependence on primary production on the various components of economic well-being. We use non-parametric regression because it allows us to visualize the impacts simultaneously and thereby permits visualization of possible confounding spatial attributes, contrary to traditional bivariate correlation analysis. The nonparametric surfaces are made with the Nadaraya-Watson estimator and can be written for multivariate predictors as (Faraway 2006)

$$
f_{\lambda}(\vec{x})=\frac{\sum_{j=1}^{n} K\left(\vec{x}-\vec{x}_{j} / \lambda\right) Y_{j}}{\sum_{j=1}^{n} K\left(\vec{x}-\vec{x}_{j} / \lambda\right)}(1),
$$

where $w_{j}=K\left(\frac{x-x_{j}}{\lambda}\right) / \lambda . \mathrm{K}$ is a kernel where $\int K=1 . \lambda$ is the bandwidth which controls the smoothness of the fitted curve and therefore determines how far away observations are allowed to be from $x$ and still contribute to the estimation of $f_{\lambda}(x)$, here to the economic wellbeing of the rural areas concerned.

Non-parametric surfaces are used to assess the impact of relative location, effective temperature sum and the proportion of fields on the economic well-being of rural areas by fitting linear regression models to the non-parametric surfaces. For this purpose the estimated surface was divided into $s \times r$ grids with a uniform scale for all the explanatory variables. These midpoints $\left(x_{s}^{k}, x_{r}^{d}\right), \mathrm{s}=1, \ldots, 19$ and $\mathrm{r}=1, \ldots, 19$, can be understood as $\mathrm{xy}$-coordinates where the values $x^{k}, k=1, \ldots, 3$, represent the variables of the spatial attributes of location, land and climate and the $x^{d}$ values represent the values for dependence on primary production.

The estimation results obtained from the non-parametric regression are saved in the matrix $Y=\left\lfloor y_{s, r}^{w}\right\rfloor$ where $s=1,2, \ldots, 19$ and $r=1,2, \ldots, 19$, where $y_{s \bullet}^{w} \in R^{19}$ denotes the $s^{\text {th }}$ row of the matrix $Y$ for $w=1, \ldots 5$, independent economic well-being variables and $x_{s \bullet} \in R^{19}$ denotes the $s^{\text {th }}$ row of the matrix $X^{k}$ for $\mathrm{k}=1, \ldots, 3$ dependent variables measuring spatial attributes. The dependent values were standardized in order to be able compare the results between variables. The linear regression models for the spatial attributes are estimated as

$$
y_{s}^{w}=\alpha_{s \bullet}^{k}+\beta_{s \bullet}^{k} x_{s \bullet}^{k}(2)
$$

Similarly, let $x_{\bullet r}^{d} \in R^{19}$ denote the $r^{\text {th }}$ column of the matrix $X^{d}$. The regression model for dependence on primary production is then defined as

$$
y_{r}^{w}=\alpha_{\bullet r}^{d}+\beta_{\bullet r}^{d} x_{\bullet r}^{d}(3) .
$$

After estimation of the regression models, the average difference in the estimated regression slopes $\left(b_{p}^{k}\right)$ can be calculated as $b_{p}^{k}=\frac{1}{n} \sum_{s=1}^{19} \beta_{s \bullet}^{k}-\frac{1}{n} \sum_{r=1}^{19} \beta_{\bullet r}^{d}$. 
In third hypothesis, to investigate whether the impact of relative location (i.e. distance) is higher than the impact of other spatial attributes on economic well-being, we applied the permutation test to assess the mean difference in the estimated regression slopes. The permutation test provides a simple means of computing the sampling distribution for any test statistic, given the null hypothesis that dependence on primary production and the other explanatory variables have similar impacts on economic well-being in rural areas on the estimated non-parametric surfaces. The permutation test was performed in five steps:

1. Draw a resample of size 19 from the first sample without replacement and a separate resample of size 19 from the second sample.

2. Compute the difference between the means for the two samples as $b_{p}^{k^{*}}=\frac{1}{19} \sum_{s=1}^{19} \beta_{s \bullet}^{k^{*}}-\frac{1}{19} \sum_{r=1}^{19} \beta_{\bullet r}^{d^{*}}$, where $\beta_{s \bullet}^{k^{*}}$ and $\beta_{\bullet r}^{k^{*}}$ are sampled regression slopes for variables of the spatial attributes and dependence on primary production, and save the results.

3. Repeat steps 1 and 2 a further $\mathrm{k}$ times to construct a bootstrap distribution for the statistic $b_{p}^{k^{*}}$

4. Sort $b_{p}^{k^{*}(l)}, I=1 \ldots, \mathrm{r}$ into increasing order, to obtain $b_{p}^{k^{*}(1)} \leq \ldots \leq b_{p}^{k^{*}(r)}$

5. Calculate the pseudo-significance level for an observed $b_{p}^{k}$ based on this distribution by comparing $b_{p}^{k^{*(\alpha)}}$ with $b_{p}^{k}$, where $\alpha$ is the selected pseudo-significance level. If $b_{p}^{k} \geq b_{p}^{k^{*}(\alpha)}$, dependence on primary production does not have a similar impact on economic well-being in rural areas to the other explanatory variables.

\subsection{Measuring economic well-being, the explanatory variables and areal units}

In order to focus our approach on economic well-being, we included variables of the proportion of people with a university degree, household income by consumption unit, household debt, household net property and the unemployment rate, data on all of which are available at the postcode area level from Statistics of Finland (SuomiCD 2006). These variables are similar to those used in many previous analyses of economic well-being in Finland (e.g. Siirilä et al. 1990; Vaattovaara 1998; Kainulainen et al. 2001; Karvonen \& Rintala 2007; Karvonen \& Kauppinen 2009) and are fairly consistent with the corresponding measures used in past studies in Canada and the United States (e.g. Stedman et al. 2004: 221; Patriquin et al. 2007). The exact definitions and years for the variables are presented in Table 1.To be consistent with past research by we use this broadened suite of indicators instead of focusing on poverty as many others have done (Stedman et al. 2004). However, we lack indicators for living conditions, such as health and environment, and happiness, such as community ties, friends, and work satisfaction. These assets have been regarded as important factors of well-being (e.g. Moss 2006).

The variable associated with the components of economic well-being in the bivariate correlation analysis is dependence on primary production, represented by the number of employees in agriculture, forestry and fishing as a proportion of the total number of employees in each postcode area. Agriculture and forestry are the two dominant resource-based sectors in rural areas in Finland, representing 55 per cent and 44 percent of total employment in primary production in 2004. The explanatory variable depicting the relative location of an area in relation to the largest cities (over 100000 inhabitants) is expressed in terms of the distance from the centroid of each postcode area to the nearest city centre. The variables indicative of regional variations in the natural potential of the land and climate are expressed by the area of the fields as a proportion of the total surface area of each postcode district as obtained from Corine Land Cover data base produced by the Finnish Environment Institute and by the effective temperature sum as recorded by the Finnish Meteorological Institute. The higher 
the proportion of the fields to the more suitable the soil may be assumed to be for agriculture, and the more viable the remnants of past rural settlement policy. The effective temperature sum indicates roughly the differences in the growing season and the suitability of the geographical position of each area, especially for primary production.

\begin{tabular}{|c|c|c|}
\hline Variable & Definition & Year \\
\hline University degree & $\begin{array}{l}\text { People with a university degree as a proportion of the total } \\
\text { population aged } 16-74 \text { years }\end{array}$ & 2003 \\
\hline Unemployment rate & $\begin{array}{l}\text { 15-74-year-old unemployed job seekers on the last day of the } \\
\text { year as a proportion of the total labour force }\end{array}$ & 2003 \\
\hline Household income & $\begin{array}{l}\text { Taxable income per household (state taxation), including } \\
\text { earnings and capital income }(€)\end{array}$ & 2004 \\
\hline Household debt & Average debts per household $(€)$ & 2004 \\
\hline $\begin{array}{l}\text { Household net } \\
\text { property }\end{array}$ & Average taxable property per household (less debts) & 2004 \\
\hline $\begin{array}{l}\text { Dependence on } \\
\text { primary production }\end{array}$ & $\begin{array}{l}\text { Employees in agriculture, forestry and fishing as a proportion } \\
\text { of all employees in the area (\%) }\end{array}$ & 2004 \\
\hline
\end{tabular}

Tab 1. Definitions of variables measuring economic well-being and dependence on primary production. The data are from the years 2003 and 2004.

The postcode area constitutes the smallest regional statistical entity based on functionality in the distribution of a service, namely the postal service. Due to limitations on the data or reporting techniques, earlier studies have typically focused on the county or municipality level a level of aggregation that obscures important community-level diversity (Mekbeb et al. 2009). Our analysis differs in this respect, as the database consists of 1856 postcode areas located in rural municipalities in 2005 (for the classification of municipalities, see Malinen et al. 2006) (Fig. 1).

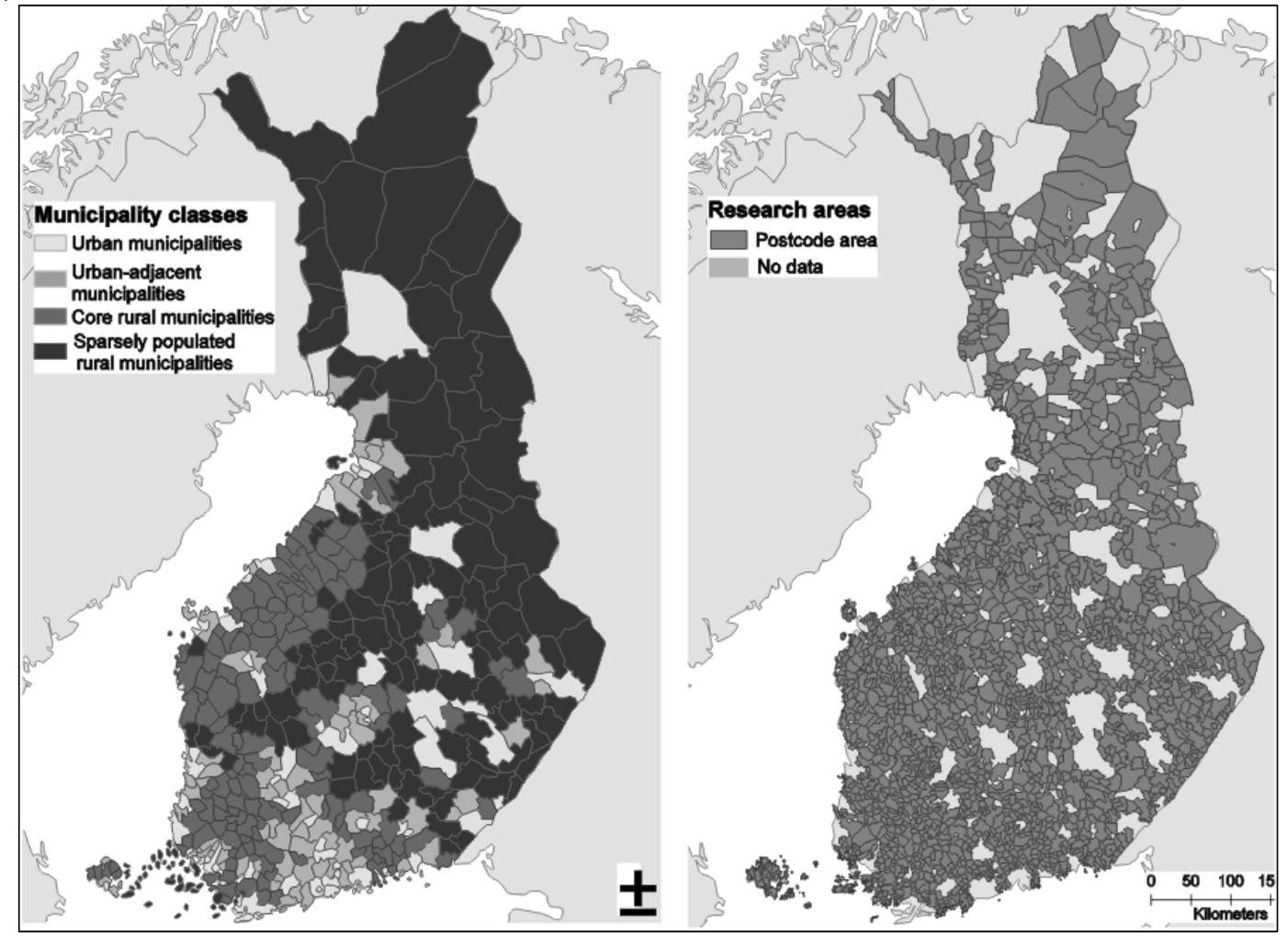

Fig 1. Rural postcode areas and municipality classes in Finland. The rural postcode areas were selected so that the majority of their total surface area was located outside urban municipalities. 


\section{Impact of dependence on primary production, location and natural conditions on the elements of economic well-being}

\subsection{The impact of dependence on primary production on economic well-being}

The results of the bivariate correlation analysis employed here to test the first hypothesis - that the constituents of economic well-being decline at the postcode area level as dependence on primary production increases - show that a decrease in the level of household income and a decrease in human capital (measured by the proportion of residents with a university degree in each postcode area) are associated with an increasing proportion of primary production (Table 2). Primary production partly explains property values in rural areas in the following way: the higher the proportion of primary production, the larger are household net assets.

Our ensuing analysis then revealed that debts in particular are better explained by distance and natural conditions. Unemployment correlates slightly but significantly with dependence on primary production. Our first hypothesis is thus proved not rejected, especially in the level of education and incomes decline as dependence on primary production increases. The situation in the case of household debt and unemployment is different, however, as the poor correlation seems to indicate that dependence on primary production is relatively insignificant and is actually a confounding factor in the relationship between economic well-being and other explanatory variables. To get a more profound understanding we next investigate the role of distance, climate and land-use in explaining the spatial distribution of well-being.

\begin{tabular}{|l|l|r|r|r|r|r|}
\hline Variable & $\begin{array}{l}\text { Correlation with } \\
\text { dependence on primary } \\
\text { production }\end{array}$ & N & Mean & SD & Min & Max \\
\hline University degree & $-0.583^{* * *}$ & 1856 & 6.24 & 3.81 & 0 & 30 \\
\hline $\begin{array}{l}\text { Household income } \\
\text { by consumption unit }\end{array}$ & $-0.464^{* * *}$ & 1856 & 23,597 & 4,795 & 13,751 & 74,327 \\
\hline Household debt $(€)$ & $0.116^{* *}$ & 1856 & 46,985 & 15,245 & 11,433 & 123,774 \\
\hline $\begin{array}{l}\text { Household net } \\
\text { property }(€)\end{array}$ & $0.382^{* * *}$ & 1856 & 56,116 & 19,057 & 8,295 & 258,941 \\
\hline Unemployment rate & $0.112^{* *}$ & 1856 & 13.79 & 7.24 & 0 & 52 \\
\hline
\end{tabular}

${ }^{*} \mathrm{p}<0.05 ;{ }^{* *} \mathrm{p}<0.01 ;{ }^{* * *} \mathrm{p}<0.001$

Tab 2. Elements of economic well-being and their correlations with dependence on primary production.

\subsection{The contributions of distance and natural conditions to economic well-being}

\subsubsection{Relations of the elements of economic well-being to dependence on primary production and distance from the nearest large city}

We started to test the second hypothesis, concerned with the underlying factors behind dependence on primary production, by comparing the explanations given by dependence on primary production and distance for each component of economic well-being, taking the level of education first. Since primary production almost solely employs specialized labour in farming and forestry, local labour markets become thinner and more one-sided, with a lower educational level, as the proportion of primary production increases (Fig. 2a, $1^{\text {st }}$ right panel; Table 3 ). Thus, the spatial variation in education levels can be explained well as the inverse of dependence on primary production. As the postcode areas cover only rural areas, the impact of distance from a large city remains less visible in educational structures, although such an impact does exist.

In contrast to the rural USA, for instance, rural unemployment in Finland is higher than urban unemployment and is concentrated in the remotest peripheries (Pehkonen \& Tervo 1998; Tervo 1998; Rusanen et al. 2001; Parker et al. 2010). Thus unemployment is highly sensitive to 
distance from a large city, and it is related to dependence on primary production in a more complex way than is revealed in Table 2 (see Fig. $2 a, 2^{\text {nd }}$ panels). The impact of dependence on primary production on unemployment is convex in form, so that relatively robust agricultural areas, where dependence is modest, have low unemployment compared with areas where dependence is very low or very high (ibid). Unemployment nevertheless plagues all rural areas in a manner that is largely independent of dependence on primary production and is explained better by relative location. In general terms, the more peripheral an area is relative to large cities, the more unbalanced its labour market is (Fig. 2a, $2^{\text {nd }}$ right panel).

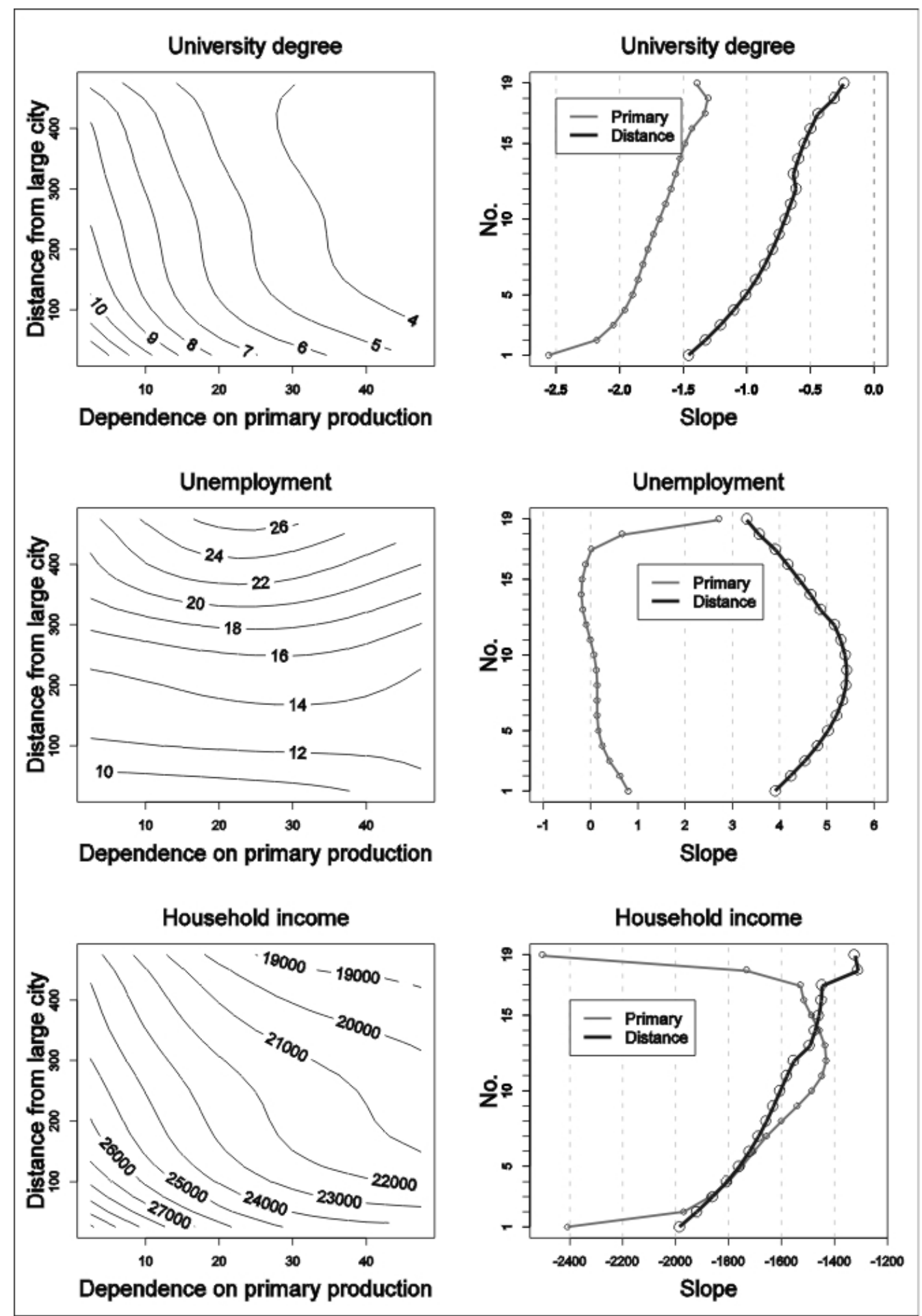

Fig 2a. Dependence on primary production, distance from the nearest large city and economic well-being. 
Economic performance in rural areas is poor in both a structural and a spatial sense, as household incomes decline with distance from the largest centres. However, this decline dampens with increasing distance (Fig. $2 \mathrm{a}, 3^{\text {rd }}$ panel) and it is the impact of the local economic structure which remains somewhat stronger in determining household incomes (Table 3). The decline of incomes smoothes out as both distance and the proportion of primary production increase, although plunges in income are found where primary production areas start and where the proportion of primary production is highest (Fig. 2a, $3^{\text {rd }}$ panel). The former reveals the interface where high-income suburban rural areas give way to primary production areas and the latter depicts very small, one-sided, poor communities in peripheries. In spite of the different tails of the slope distributions, the regression slopes behave similarly in the main, and there is no significant difference in explanatory power between distance from a centre and dependence on primary production, but the latter does provide a slightly better explanation in a rural setting (Table 3).

\begin{tabular}{|l|l|r|l|}
\hline Variable & Independent variables & Mean slope & Permutation \\
& & p-value \\
\hline \multirow{3}{*}{ University degree } & Resource & $\mathbf{- 1 . 7 2 5}$ & $<0.001$ \\
\cline { 2 - 3 } & Distance & -0.773 & \\
\hline \multirow{2}{*}{ Unemployment } & Resource & 0.288 & $<0.001$ \\
\cline { 2 - 3 } & Distance & $\mathbf{4 . 6 6 2}$ & \\
\hline Household income & Resource & $\mathbf{- 1 7 0 1 . 8 5}$ & \multirow{2}{*}{0,169} \\
\cline { 2 - 3 } & Distance & -1618.76 & \\
\hline Household debt & Resource & 2317.295 & $<0.001$ \\
\cline { 2 - 3 } & Distance & $\mathbf{- 9 1 5 5 . 2 2}$ & \\
\hline Household net property & Resource & $\mathbf{7 9 5 4 . 6 2 3}$ & $<0.001$ \\
\cline { 2 - 3 } & Distance & -4024.18 & \\
\hline
\end{tabular}

Tab 3. Results of the permutation test on the slopes of dependence on primary production and distance. The main contributing factors are in bold and confounding factors in italics.

Household debts usually indicate investments in housing and anticipate future growth in the locality concerned, an expectation of a kind that does not exist to any great extent in marginal, declining areas. In the present case household debt decreases with increasing distance and with decreasing dependence (Fig. 2b, $1^{\text {st }}$ right panel). The permutation test demonstrates that the impact of distance predominates (Table 3 ). The very strong dependence on distance is explained by the fact that most debtor households are concentrated in areas located close to large cities, as the highest debts belong mostly to commuters who have invested in housing. This means that dependence on primary production is a weak, confounding factor for the spatial variation in household debts. In part it is mixed with the larger investing grain farms situated in wealthier regions near to larger cities (Myyrä \& Pietola 2001), but in general the result reveals that if distance is constant an increase in primary production increases debts in a rural area slightly.

Growing dependence on primary production increases the net value of a household's property but to the trend decelerates once specialization has reached a certain point. The increase is the result of an increase in capital-intensive primary production and the value of the industrial capital invested (Fig. 2b, $2^{\text {nd }}$ panels). The influence of robust farming areas is seen in the change in the rapidly growing slope coefficients, whereas in the areas that have specialized most in primary production the increase in net property values levels off (Fig. $2 b, 2^{\text {nd }}$, right panel). Even so, the impact of dependence on primary production on the net value of a rural household's property is higher than the impact of distance (Table 3). The impact of the proximity of a large city on net property values is explained by the higher value of houses and other properties brought about by wealthier households and increasing competition for residential 
land in the vicinity of urban areas (Fig. $2 b, 2^{\text {nd }}$, left panel). The inverse S-shape of the contours reveals that net property values in semi-peripheral areas remain rather stable in relation to distance $\left(150-300 \mathrm{~km}\right.$ ), except in the remotest peripheries, where they fall (Fig. $2 \mathrm{~b}, 2^{\text {nd }}$, left panel). In practice, the postcode areas with very low values are found in eastern and northern parts of the country. Hence, current development is clearly urban-driven, as shown in Finland and elsewhere (e.g. Anselin et al. 1997; Gløersen et al. 2005; Partridge et al. 2007; Partridge et al. 2008; Tervo 2009). Peripheral areas combined with low productivity estates are less profitable and household incomes in general are lower, and hence net property values do not accumulate in households.

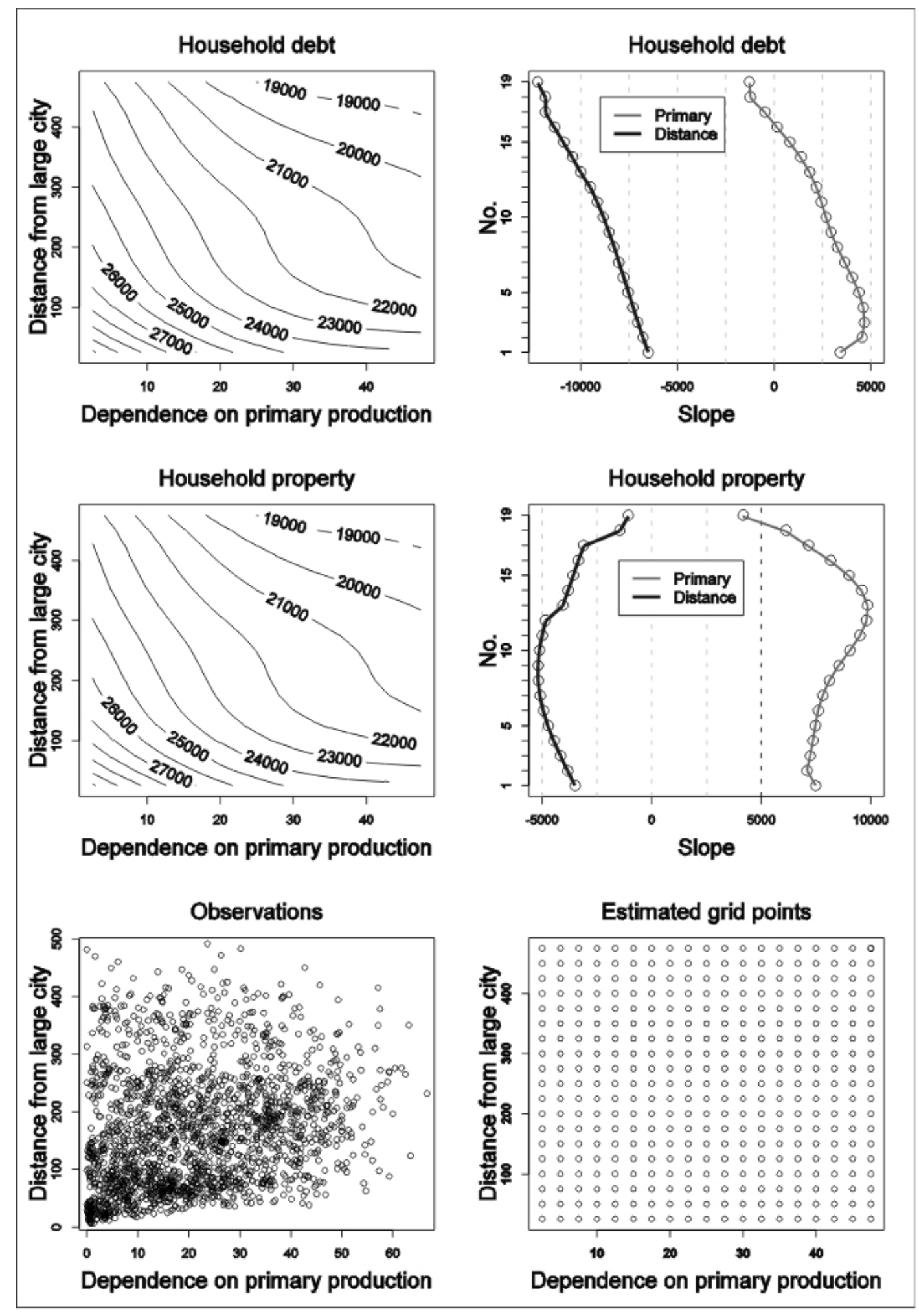

Fig $2 b$. Dependence on primary production, distance from the nearest large city and economic well-being. 


\subsubsection{Elements of economic well-being and their relations to effective temperature sum and dependence on primary production}

The impact of climatic conditions, in practice geographical location on a north-south axis, represents a strong explanatory factor (Fig. 3, Table 4), explaining four out of the five components of economic well-being better than does dependence on primary production, and it only does not outweigh the impact of dependence on primary production in explaining the level of education (Fig. 3a, $1^{\text {st }}$ panel, Table 4). Due to the nature of the production processes involved, dependence on primary production lowers the educational level most, with the lowest proportions of people with a university degree being concentrated in areas which have a low effective temperature sum, in northern Finland. Dependence on primary production has the greatest effect, but every warmer, more southerly location has a higher level of educated human capital available for generating economic development than more northerly ones with a comparable dependence on primary production (Fig. 3a, $1^{\text {st }}$ left panel). Climatic conditions constitute the main underlying driver behind the rest of the components, pointing to an evident discrepancy on a south-north national core-periphery scale in Finland.

\begin{tabular}{|c|c|c|c|}
\hline Variable & Independent variables & Mean slope & Permutation p-value \\
\hline \multirow[t]{2}{*}{ University degree } & Resource & $-1,73$ & \multirow{2}{*}{$<0.001$} \\
\hline & ETS & 1,163 & \\
\hline \multirow[t]{2}{*}{ Unemployment } & Resource & 0,891 & \multirow{2}{*}{$<0.001$} \\
\hline & ETS & $-6,199$ & \\
\hline \multirow[t]{2}{*}{ Household income } & Resource & $-1624,38$ & \multirow{2}{*}{$<0.001$} \\
\hline & ETS & 2225,558 & \\
\hline \multirow[t]{2}{*}{ Household debt } & Resource & 2121,2 & \multirow{2}{*}{$<0.001$} \\
\hline & ETS & 9663,227 & \\
\hline \multirow[t]{2}{*}{ Household net property } & Resource & 6615,64 & \multirow{2}{*}{$<0.001$} \\
\hline & ETS & 10992,59 & \\
\hline
\end{tabular}

Tab 4. Results of the permutation test on the slopes of dependence on primary production and effective temperature sum (ETS). The main contributing factors are in bold and confounding factors in italics.

As found earlier, the unemployment rate is poorly explained by dependence on primary production (Table 2; Fig. 3a, $2^{\text {nd }}$ panel). The areas of low unemployment at any level of dependence on primary production are located in areas with climatically favourable conditions. Hence, ETS has a much stronger association with unemployment than does dependence on primary production, the impact of which is marginal (Table 4). Remote, cold environments were intensively colonized by farming and forestry in the past, and increased productivity with a relatively stable output has caused high unemployment. Nowadays the highest estimated unemployment rates occur in areas where dependence on primary production is about 15 to 40 percent (Fig. 3a, $2^{\text {nd }}$ panel), whereas the situation is much less serious under better climatic conditions. Thus the shape of the contours indicates that unemployment in cold northern rural areas is worsened by dependence on primary production. 


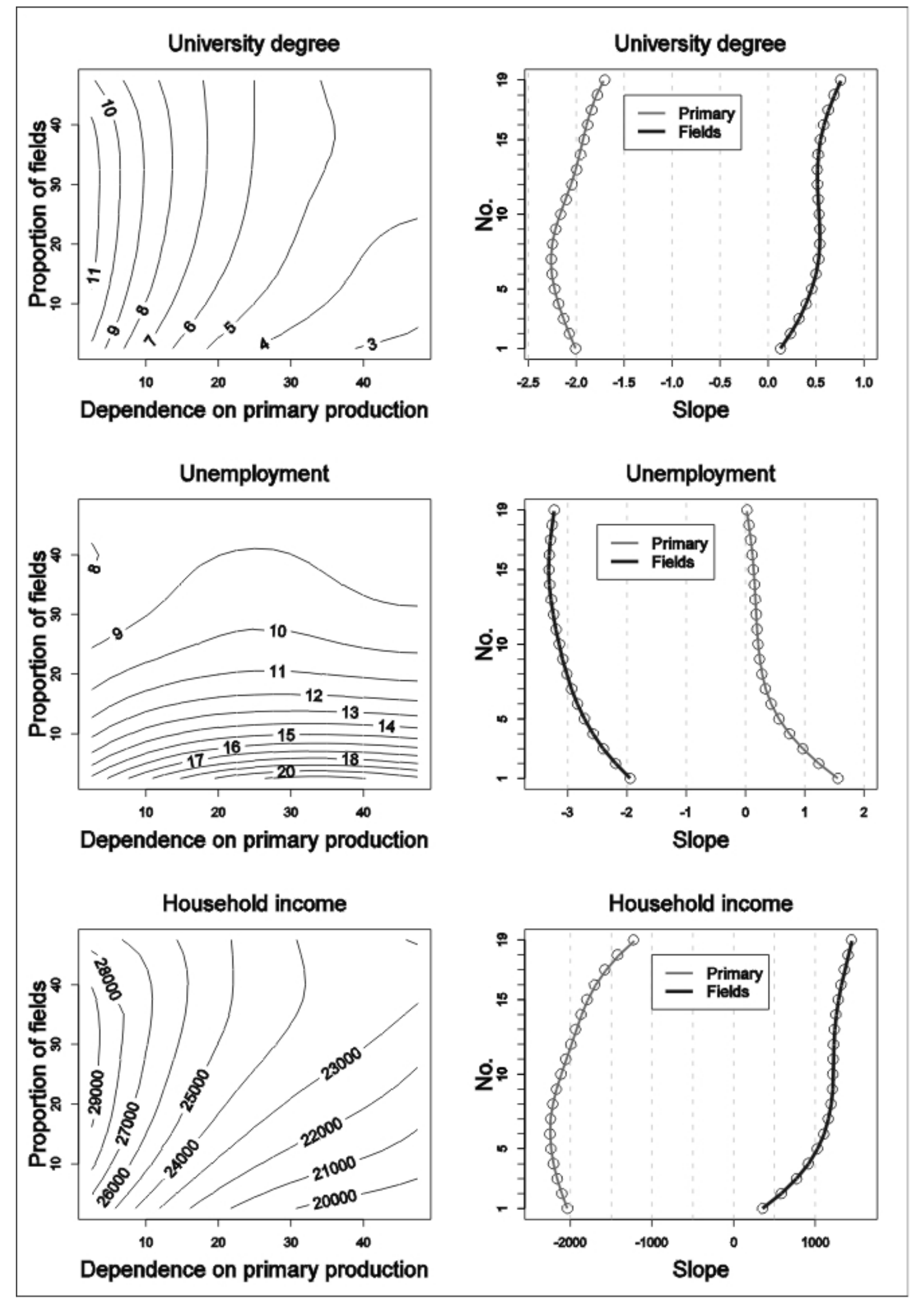

Fig 3a. Dependence on primary production, effective temperature sum (ETS) and economic well-being. 


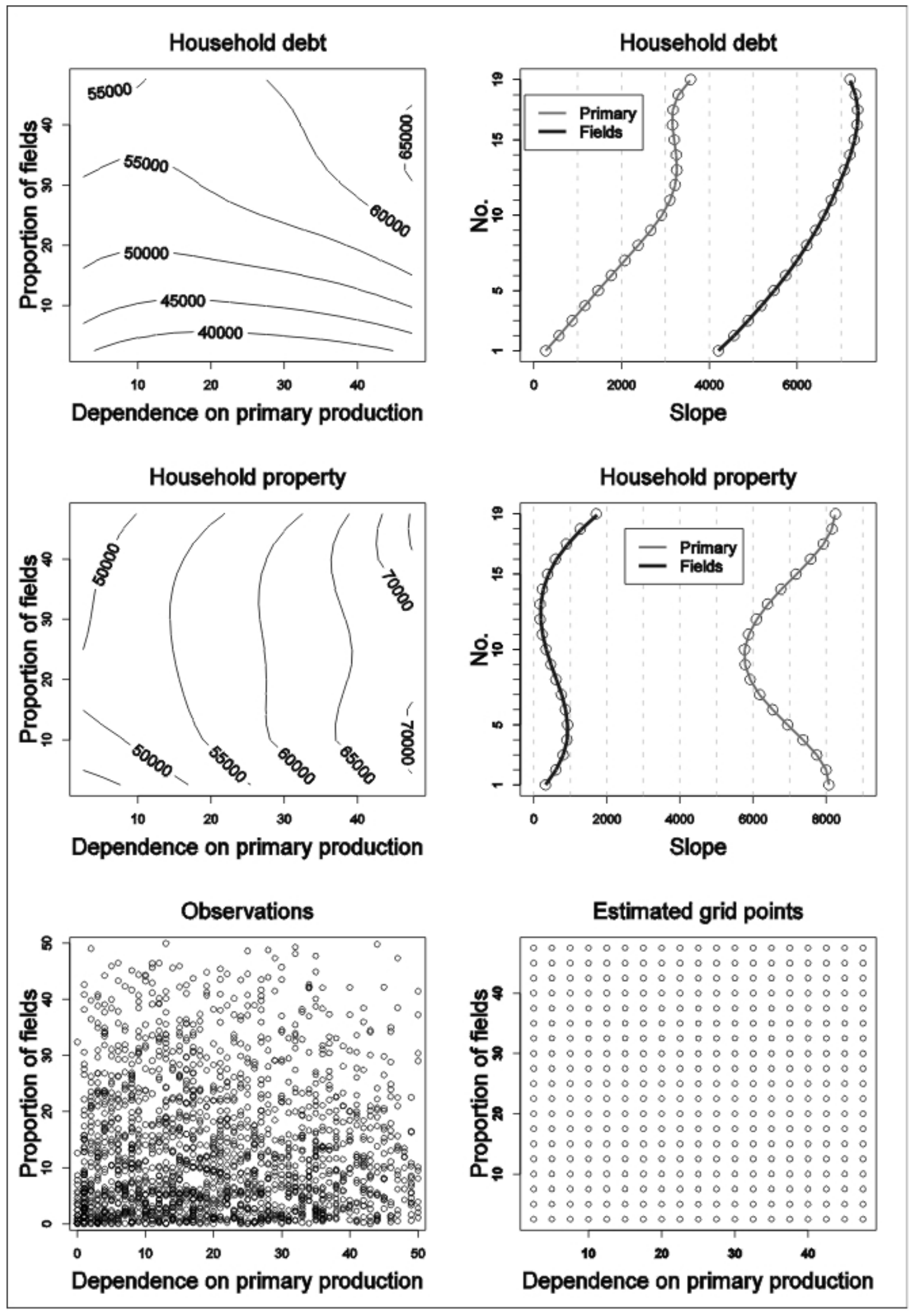

Fig 3b. Dependence on primary production, effective temperature sum and economic well-being.

Apart from a few localities, there are pressures to reduce the population in areas where maintaining population levels is costly. Cold, remote regions are not granted such large subsidies, or else their productivity remains low and no new industries emerge. Hence incomes usually decline in relative terms. Household incomes decrease the colder the location of an area 
and the region depends on primary production. However, in highly resource-dependent areas incomes do not rise very high even when the climate is favourable (Fig. $3 a, 3^{\text {rd }}$ panel). These associations indicate that cold climatic conditions lead to lower pecuniary well-being in addition to some degree of dependence on primary production. A cold climate creates costs, which worsen the socio-economic position of the local people, especially when the government ceases to invest in or subsidize frontier resource areas, as seen in many instances (Hill \& Gaddy 2003; Markey et al. 2006; Cooke \& Leydesdorff 2006). Hence, the decline in local remote economies in cold environments and out-migration from such places will easily accelerate as the impact of market rules increases.

One corollary arising from the above tendencies for regression in economic development is that household investments financed by debt remain low in cold environments. Household debts increase the more favourable the climate is (in terms of ETS) and the higher the weight attached to primary production (Fig. $3 \mathrm{~b}, 1^{\text {st }}$ panel). In such a situation the impact of dependence on primary production is again lower than that of climatic conditions, whereupon dependence on primary production becomes a weak confounding factor as far as household debts are concerned (Table 4). Households naturally invest in housing and productive capital, but it is a favourable location with good climatic conditions and jobs available which matters most. In practice, the result points to a shift in the intensity of household investments from the rural north and northeast towards more favourable climatic conditions.

The pattern of household net property resembles that of household debt to some extent, and dependence on primary production has an obvious impact on net property values (Fig. $3 \mathrm{~b}, 2^{\text {nd }}$ panel). Again climatic conditions have a higher impact than dependence on primary production, however, which reduces the latter to a weak confounding factor (Table 4). The areas of the highest property values are located in the south and are dominated by primary production. The spatial patterns of household debt and household net property reflect differences in the pace of economic activity and the valuation of land and other assets between north eastern and northern parts of the country and the south. The differences in the contributions made to production factors, which in turn are mirrored by differences in economic well-being, indicate that after the resource frontier phase and the colonization of the peripheries the means of production tend to concentrate in climatically more favourable areas, which is the main reason for differences in property values.

\subsubsection{Dependence on primary production, the proportion of fields and economic well- being}

The intensity of land use for agriculture, as measured by the field area as a proportion of the total surface area of a postcode district, has minor impacts on the spatial patterns of most components of economic well-being, as indicate by the vertical contour lines in Fig. $4 \mathrm{a}\left(1^{\text {st }}\right.$ and $3^{\text {rd }}$ panels) and Fig. 4b ( $1^{\text {st }}$ panel). Unemployment and household debt are the components of economic well-being which are explained better by the proportion of fields than by dependence on primary production (Table 5).

As shown earlier, increasing dependence on primary production strengthens the non-academic aspect of the occupation structure, whereas an increasing proportion of fields has a weak but positive association with a higher level of education (Fig. 4). In practice this refers to more intensive land use, usually taking place under better climatic conditions and closer to larger cities, where the level of education is higher than in the periphery, although the impact of the proportion of fields is smaller than the contrary impact of dependence on primary production (Table 5). Both dependences reflect the spatially selective nature of development, as educational levels are affected differently in robust areas and in resource-dependent peripheries (cf. Tables 3 and 5). 


\begin{tabular}{|c|c|c|c|}
\hline Variable & Independent variables & Mean slope & Permutation $p$-value \\
\hline \multirow[t]{2}{*}{ University degree } & Resource & $-2,052$ & \multirow{2}{*}{$<0.001$} \\
\hline & Proportion of fields & 0,496 & \\
\hline \multirow[t]{2}{*}{ Unemployment } & Resource & 0,403 & \multirow{2}{*}{$<0.001$} \\
\hline & Proportion of fields & $-2,957$ & \\
\hline \multirow[t]{2}{*}{ Household income } & Resource & $-1966,68$ & \multirow{2}{*}{$<0.001$} \\
\hline & Proportion of fields & 1120,164 & \\
\hline \multirow[t]{2}{*}{ Household debt } & Resource & 2391,283 & \multirow{2}{*}{$<0.001$} \\
\hline & Proportion of fields & 6310,415 & \\
\hline \multirow{2}{*}{$\begin{array}{l}\text { Household net } \\
\text { property }\end{array}$} & Resource & 6971,596 & \multirow{2}{*}{$<0.001$} \\
\hline & Proportion of fields & 648,313 & \\
\hline
\end{tabular}

Tab 5. Results of the permutation test on the slopes of dependence on primary production and the proportion of fields. The main contributing factors are in bold and confounding factors in italics.

The most robust areas with low unemployment are ones which have a high proportion of fields combined with high dependence on primary production or a very diverse economic structure (Fig. 4a, $2^{\text {nd }}$ panel). The latter situation, indicated by low dependence on primary production, refers to commuter areas and small industrial centres, which, if they are also strong farming areas, will have low unemployment.

As expected in view of more viable farming, household income is positively but weakly correlated with the proportion of fields but negatively with dependence on primary production (Table 5, Fig. 4a, $3^{\text {rd }}$ panel). The results indicate that a low intensity of rural land use pushes income levels down, as they are higher in areas which have more intensive arable land use at the same level of dependence on primary production.

Capital is needed for running large-scale farms and for house construction, which will tend to increase debts. Thus rising household debts are better explained by an increasing proportion of fields than by dependence on primary production. This pattern is the result of investments carried out on larger farms, so that this type of increase in household debt is better distinguishable with higher proportions of fields. The major debt upslope, however, comes from housing investments in the proximity of a city in climatically favourable areas (cf. the respective slope coefficients in Tables 3 and 4). This gives an estimate of how rural areas will segregate spatially in the future, showing that centripetal forces are strong and that rural development in economic well-being will diverge spatially.

The pattern of household net properties reveals that primary production pushes this measure up more than does the proportion of fields (in Fig. $4 \mathrm{~b}, 1^{\text {st }}$ panel). Comparing this with earlier results, we must conclude that specialized, often large farms in economically diversified environments are indebted, whereas an increase in dependence on primary production indicates an increase in people's possession of forest properties, which are not usually financed by loans. This is in accordance with the interpretation of increasing debts as being associated with the proportion of field area (Table 5 and Fig. 4b, $2^{\text {nd }}$ panel). Nevertheless, high net property values are more a result of location in more southerly, climatically warm areas which benefit from the proximity of a city (cf. Fig. 3b, $2^{\text {nd }}$ panel and Fig. 4b, $2^{\text {nd }}$ panel). 


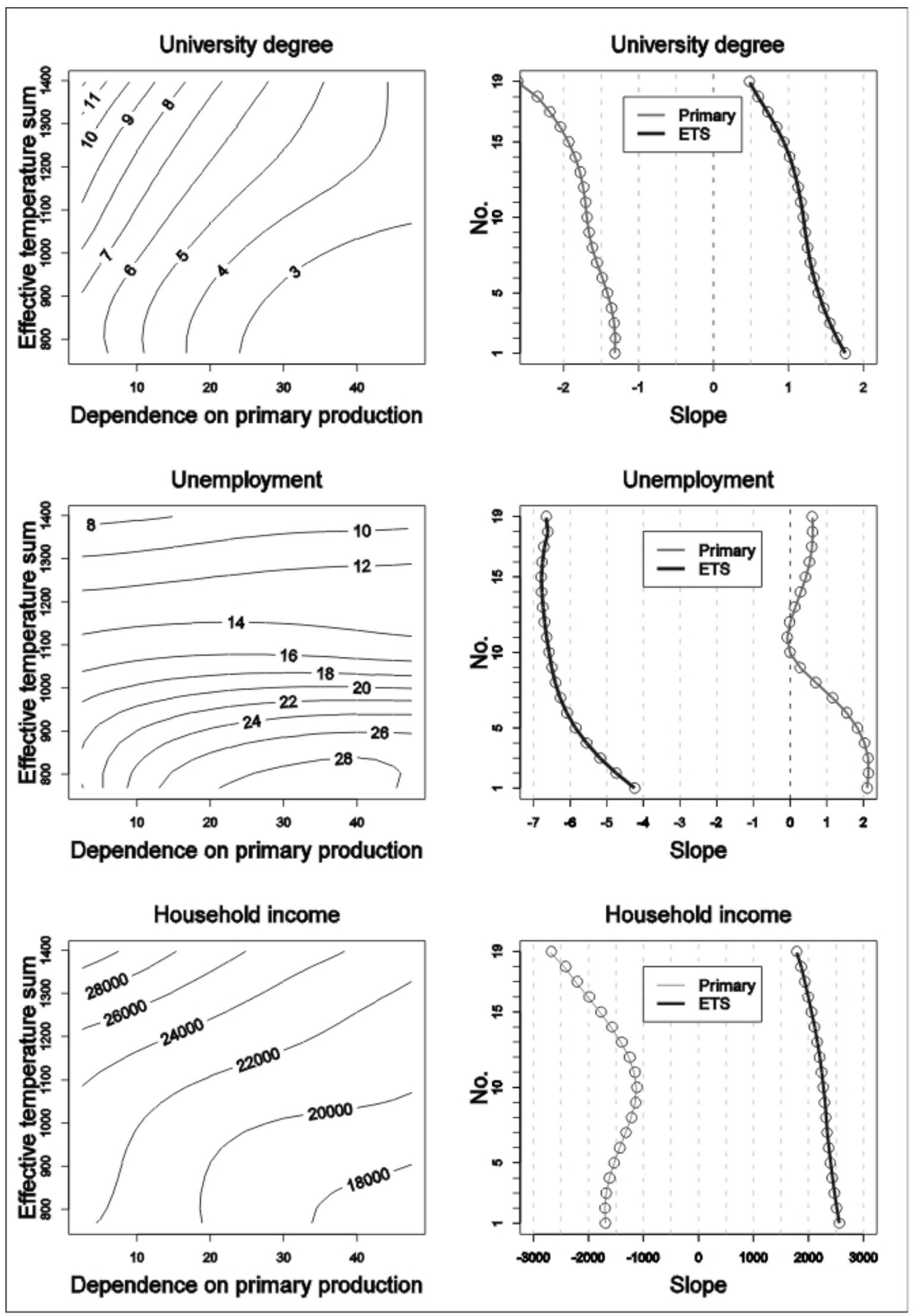

Fig 4a. Dependence on primary production, proportion of fields and economic well-being. 


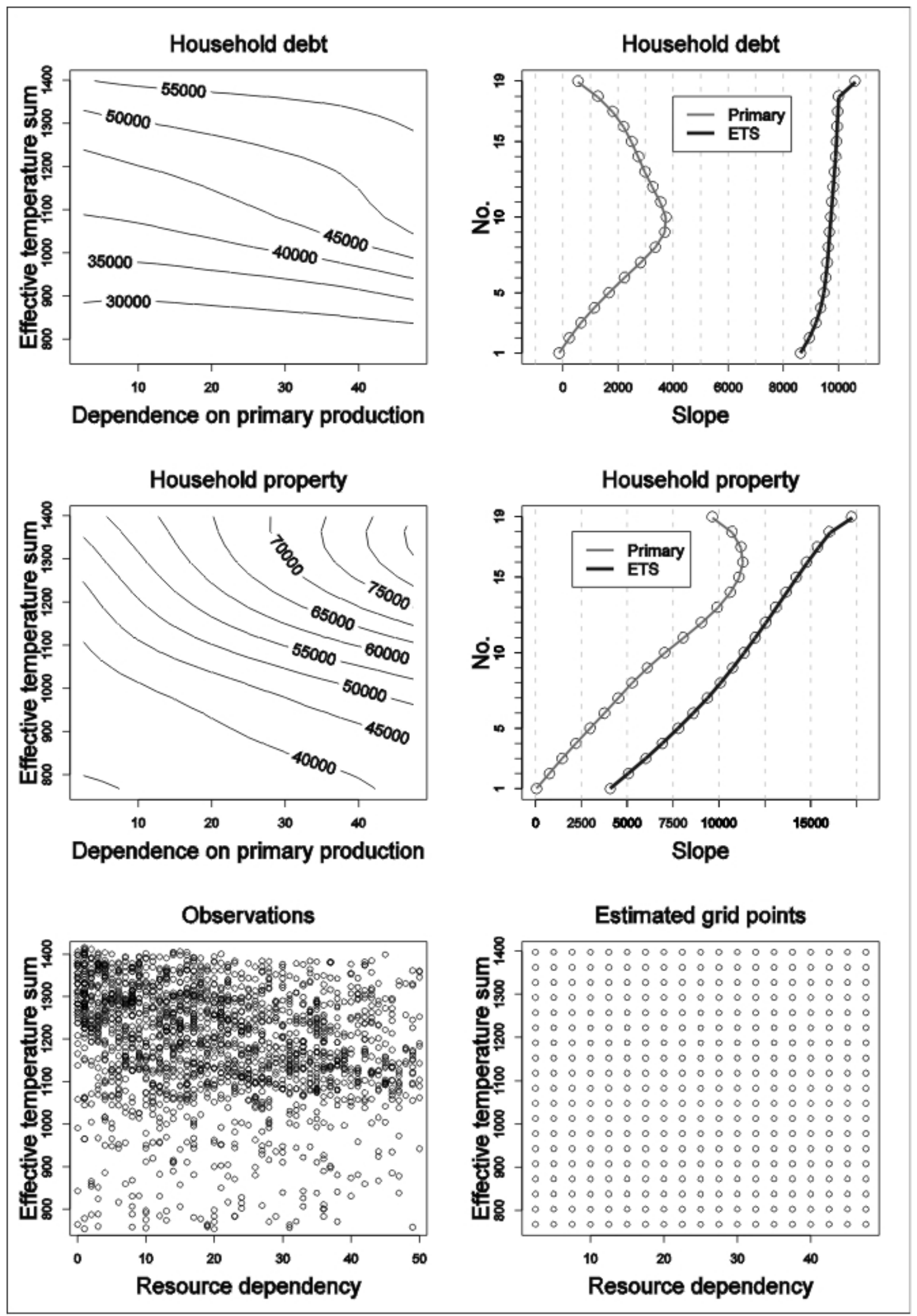

Fig 4b. Dependence on primary production, proportion of fields and economic well-being. 


\subsection{Comparison of the impacts of relative location and physical attributes}

In the third hypothesis we assumed that the impact of relative location on the economic wellbeing of rural areas is greater than that of climate or the proportion of fields. The test revealed that ETS overrides distance in its impacts on four elements of economic well-being, and that the results are significant (Table 6). Only the average household debt by postcode area, in practise large investments by households in rural exurbia and the decay in economic activities, mostly farming, towards the periphery, leads to the explanation that distance and ETS are approximately equally powerful explanatory variables and ETS gives a better explanation. Distance overrides the proportion of fields in explaining every component of economic wellbeing (Table 6). Hence we reject the hypothesis that the impact of relative location is greater than that of natural conditions on the economic well-being of rural areas, at least as far as climatic conditions are concerned.

\begin{tabular}{|c|c|c|c|c|c|c|}
\hline Variable & $\begin{array}{l}\text { Independent } \\
\text { variables }\end{array}$ & $\begin{array}{l}\text { Mean } \\
\text { slope }\end{array}$ & $\begin{array}{l}\text { Permutation } \\
\text { p-value }\end{array}$ & $\begin{array}{l}\text { Independent } \\
\text { variables }\end{array}$ & $\begin{array}{l}\text { Mean } \\
\text { slope }\end{array}$ & $\begin{array}{l}\text { Permutation } \\
\text { p-value }\end{array}$ \\
\hline \multirow{2}{*}{$\begin{array}{l}\text { University } \\
\text { degree }\end{array}$} & ETS & 1,163 & \multirow[t]{2}{*}{$<0.001$} & Fields & 0,49605 & \multirow{2}{*}{$<0.001$} \\
\hline & Distance & 0,7731 & & Distance & 0,7731 & \\
\hline \multirow[t]{2}{*}{ Unemployment } & ETS & 6,199473 & \multirow[t]{2}{*}{$<0.001$} & Fields & 2,95775 & \multirow[t]{2}{*}{$<0.001$} \\
\hline & Distance & 4,662896 & & Distance & 4,662896 & \\
\hline \multirow{2}{*}{$\begin{array}{l}\text { Household } \\
\text { income }\end{array}$} & ETS & 2225,559 & \multirow[t]{2}{*}{$<0.001$} & Fields & 1120,165 & \multirow[t]{2}{*}{$<0.001$} \\
\hline & Distance & 1618,76 & & Distance & 1618,76 & \\
\hline \multirow[t]{2}{*}{ Household debt } & ETS & 9663,228 & \multirow[t]{2}{*}{0,8745} & Fields & 6310,416 & \multirow[t]{2}{*}{$<0.001$} \\
\hline & Distance & 9155,22 & & Distance & 9155,22 & \\
\hline \multirow{2}{*}{$\begin{array}{l}\text { Household } \\
\text { property }\end{array}$} & $\begin{array}{l}\text { ETS } \\
\end{array}$ & 10992,59 & \multirow[t]{2}{*}{$<0.001$} & Fields & 648,3134 & \multirow[t]{2}{*}{$<0.001$} \\
\hline & Distance & 4024,183 & & Distance & 4024,183 & \\
\hline
\end{tabular}

Tab 6. Results of the permutation test on the slopes of pairs of selected variables. The main contributing factors are in bold and confounding factors in italics.

In the above comparative setting involving three variables (Table 6) the impact of distance was more powerful than that of the proportion of fields, but climatic conditions explained economic well-being best. If the spatial economic system continues to become concentrated on account of the economies of agglomeration and restructuring of the former industrial base, the climatically least appealing, remotest and least productive areas will remain poor in terms of economic wellbeing and productive capital. This implies that the situation will maintain a state of spatial imbalance, which in turn will fulfill the logic of Krugman's theory in the sense that this imbalance will lead to a gradual spatial reorganization of the Finnish country side.

\section{Discussion and conclusions}

Our results indicate that the components of economic well-being in rural Finland are best explained by the effective temperature sum, with distance as the second best explanatory variable, followed by dependence on primary production and lastly the proportion of fields. The strong economic performance achieved by countries in the temperate zone has been demonstrated in the literature, and the same tendency is found here at the regional level as the productivity of land and labour increases. The differences in economic well-being indicate an ongoing spatio-economic shift in the factors of production from a resource-based to an urban-centric knowledge economy located in climatically more favourable parts of the country. Moreover, the differences indicate the potential for a continuation in this shift. At least two spatial economic processes can be identified on the basis of the results. 
First, Finland's spatio-economic structure is highly unbalanced from the viewpoint of a geographically efficient use of labour. Unemployment is high in the peripheries, and economic activity is dependent on the network of centres as indicated by the urban-centric accumulation of investments as measured in terms of household debts and properties. A knowledge economy provides an increasing number of jobs, intensifies the demand for a more educated labour force, gives better incomes and creates higher property values than resource-based economic activities, especially in peripheral areas, where production is less efficient and less productive. The paradox in this is that regional and welfare policies which were created to reduce spatial discrepancies have in fact managed to create a more unbalanced regional economic situation than economies which are stronger and led by market mechanisms (Puga 2002). The balancing mechanisms which Krugman's theory includes do not work well, but the centripetal mechanisms assumed in the theory do work and generate an inflow of resources towards the urbanized areas.

Second, economies of scale and increases in productivity in agriculture and forestry create a polarized pattern of development which arises out of the components of economic well-being, which also constitute the central part of the production factors, namely human, financial and educational capital. Our analysis of the physical variables confirmed that a climatically favourable location close to large cities combined with intensive agricultural land use engenders areas with a relatively high level of economic well-being. Such conditions also generate a higher accumulation of capital, i.e. the sum of net properties and debts, and higher incomes in intensively cultivated rural areas. Production is capital-intensive, as revealed by the high debt figures. Hence, it is not necessarily primary production per se which creates low economic wellbeing but other factors, such as natural conditions and relative location. The only element of well-being which is decisively determined by dependence on primary production is educational capital, causing a bottleneck preventing rural areas from becoming competitive, and hence attractive to new knowledge-intensive industries.

Regional variations in climate, relative location and land use affect local economic well-being via the spatially divergent performance of production, manifesting itself in spatial differences in household incomes and resulting in the re-investment of assets and a shift in employment from less profitable areas to more lucrative ones. The impact of a lower effective temperature sum is to increase the costs of primary production in particular, which is not now compensated for in the same way in Finland as formerly, as the economy is more open than earlier and the impact of absolute advantage matters more. Under such conditions, migration would balance the spatial distribution of production factors if the competitiveness of rural areas couldn't be improved, or if the demand for commodities which benefit from being located in rural areas does not grow. The prevalence of fields evolved in response to regional variations in the natural fertility of the land and climate, causing agriculture to cluster in robust areas in the south. The spatial inequalities and their links with dependence on primary production can lead easily to its interpretation as the root cause of inequalities, which is actually is a spurious relation. It is just one layer detracting from former investments. Our results mirror the current economic evolution towards a service economy and knowledge society and the spatial manifestations of remnant economic structures in disadvantageous locations.

References

[1] Andaluz, J., Lanaspa L. \& Sanz, F. (2002). Geographical Dynamics: A Sectoral Comparison Between the Economic Landscapes of the United States and Europe. Regional Studies, 36(4), 321-332. Doi: 10.1080/00343400220131106.

[2] Anselin, L., Varga, A. \& Arcs, Z. (1997). Local geographical spillovers between university research and high technology innovations. Journal of Urban Economics, 42(3), 422-448. Doi: 10.1006/juec.1997.2032.

[3] Castells, M. \& Himanen, P. (2002). The Information Society and the Welfare State. Oxford: Oxford University Press. 
[4] Colecchia A. \& Schreyer P. (2002). ICT Investment and Economic Growth in the 1990s: Is the United States a Unique Case? A Comparative Study of Nine OECD Countries. Review of Economic Dynamics, 5(2), 408-442. Doi: 10.1006/redy.2002.0170.

[5] Cooke, P. \& Leydesdorff, L. (2006). Regional Development in the Knowledge-Based Economy: The Construction of Advantage. Journal of Technology Transfer, 31(1), 5-15. Doi: 10.1007/s10961-005-5009-3.

[6] Cutrini, E. (2010). Specialization and Concentration from a Twofold Geographical Perspective: Evidence from Europe. Regional Studies, 44(3), 315-336. Doi: $10.1080 / 00343400802378743$.

[7] Espon Project 2.1.3. The territorial impact of CAP and rural development policy. http://www.espon.eu/main/Menu_Projects/Menu_ESPON2006Projects.html (accessed March 3, 2010).

[8] Freudenburg, W. \& Gramling, R. (1994). Natural resources and rural poverty: A closer look. Society and Natural Resources, 7(1), 5-22. Doi: 10.1080/08941929409380841.

[9] Gallup, J., Sachs, J. \& Mellinger, A. (1999). Geography and Economic Development. International Regional Science Review, 22(2), 179-232.

Doi: $10.1177 / 016001799761012334$.

[10] Gløersen, E., Dubois, A., Copus A. \& Schürmann, C. (2005). Northern Peripheral, Sparsely Populated Regions in the European North, Nordregio Report 2005, 4.

[11] Heleniak, T. (2009). The role of attachment to place in migration decisions of the population of the Russian North, Polar Geography, 32(1), 31-60. Doi: 10.1080/10889370903000398.

[12] Hill, F. \& Gaddy, C. (2003). The Siberian Curse: How Communist Planners Left Russia Out in the Cold. Washington D.C: The Brookings Institution.

[13] Jalava J. \& Pohjola M. (2007). ICT as a source of output and productivity growth in Finland. Telecommunications Policy, 31(8-9), 463-472. Doi: 10.1016/j.telpol.2007.05.011.

[14] Kainulainen, S., Rintala, T. \& Heikkilä, M. (2001). Hyvinvoinnin alueellinen erilaistuminen 1990-Iuvun Suomessa. Tutkimuksia 114. Helsinki: STAKES.

[15] Kangasharju, A. \& Pekkala, S. (2004). Increasing regional disparities in the 1990s: The Finnish experience. Regional Studies, 38(3), 255-267.

Doi: 10.1080/003434042000211097.

[16] Karvonen, S. \& Kauppinen, T. (2009). Kuinka Suomi jakautuu 2000-luvulla? Yhteiskuntapolitiikka, 74(5), 467-486.

[17] Karvonen, S. \& Rintala T. (2007). Maakuntien sisäiset hyvinvointierot. Yhteiskuntapolitiikka, 72(4), 410-416.

[18] Krugman, P. (1991). Increasing returns and economic geography. The Journal of Political Economy, 99(3), 483-499.

[19] Leake, N., Adamowicz, W. \& Boxall, P. (2006). An Econometric Analysis of the Effect of Forest Dependence on the Economic Well-being of Canadian Communities. Forest Science, 52(3), 595-604.

[20] Lundholm, E 2007. New Motives for Migration? On Interregional Mobility in the Nordic Countries. GERUM 2007:2.

[21] Machlis, G, Force, J. \& Burch, W. (1990). Timber, minerals and social change: an explaratory test of two resource dependent communities. Rural Sociology, 55(3), 411424. Doi: 10.1111/j.1549-0831.1990.tb00691.x.

[22] Malinen, P., Kytölä L., Keränen, H. \& Keränen, R. (2006). Suomen maaseututyypit 2006 Helsinki: Maa- ja metsätalousministeriö. 
[23] Markey, S., Halseth, G. \& Manson, D. (2006). The Struggle to Compete: From Comparative to competitive advantage in Northern British Columbia. International Planning Studies, 11(1), 19-39. Doi: 10.1080/13563470600935016.

[24] Mekbeb, E., Lilieholm, R., Blahna, D. \& Kruger, L. (2009). Resource use, dependence and vulnerability: community-resource linkages on Alaska's Tongass National Forest. Ecosystems and Sustainable Development, 122, 263-272.

[25] Moss, L. (2006). The Amenity Migrants: Ecological Challenge to Contemporary Shangri-La. In Moss, L. (Eds.), The Amenity Migrants. Seeking and sustaining mountains and their cultures (pp. 3-26). Trowbridge, Cromwell Press.

[26] Mukkala, K. (2004). Agglomeration Economies in the Finnish Manufacturing Sector. Applied Economics, 36(21), 2419-2427. Doi: 10.1080/0003684042000287655.

[27] Myyrä S. \& Pietola K. (2005). Velkojen keskittymiskehitys Suomen maatiloilla. Jokioinen: MTT.

[28] Overdevest, C. \& Green, G. (1995). Forest dependence and community well-being: A segmented market approach. Society \& Natural Resources: An International Journal, 8(2), 111-131. Doi: 10.1080/08941929509380906.

[29] Papyragis, E. and Gerlagh, R. (2007). Resource abundance and economic growth in the United States. European Economic Review, 51(4), 1011-1039. Doi: 10.1016/j.euroecorev.2006.04.001.

[30] Parker, T., Kusimn, L., \& Marre, A. (2010). Economic Recovery: lessons Learned from Previous Recessions. Amber Waves, 8(3), 42-47.

[31] Partridge, M. (2010). The duelling models: NEG vs amenity migration in explaining US engines of growth. Papers in Regional Science 89(3), 513-537. Doi: 10.1111/j.14355957.2010.00315.x.

[32] Partridge, M., Bollman, R., Olfert, M. \& Alasia, A. (2007). Riding the wave of urban growth in the countryside: Spread, backwash or stagnation? Land Economics, 83(2), 128-152. Doi: 10.3368/le.83.2.128.

[33] Partridge, M., Rickman D., Kamar A. \& Olfert M. (2008). Lost in space: population growth in the American hinterlands and small cities. Journal of Economic Geography, 8(6), 727-757. Doi: $10.1093 / \mathrm{jeg} / \mathrm{lbn} 038$.

[34] Patriquin, M., Parkins, J. \& Stedman, R. (2007). Socio-economic status of boreal communities in Canada. Forestry, 80(3), 279-291. Doi: 10.1093/forestry/cpm014.

[35] Pehkonen, J. \& Tervo H. (1998). Persistence and Turnover in Regional Unemployment Disparities. Regional Studies, 32(5), 445-458. Doi: 10.1080/00343409850116844.

[36] Polèse, M. \& Shearmur, R. (2004). Is Distance Really Dead? Comparing Location Patterns over Time in Canada. International Regional Science Review, 27(4), 431-457. Doi: $10.1177 / 0160017604267637$.

[37] Puga, D. (2002). European regional policies in light of recent location theories. Journal of Economic Geography, 2(4), 373-406. Doi: 10.1093/jeg/2.4.373.

[38] Pyykkönen, P. (2001). Maatalouden rakennemuutos eri alueilla. Helsinki: Pellervo Economic Research Institute.

[39] Rusanen, J., Muilu T., Colpaert, A. \& Naukkarinen. A. (2001). Finnish socio-economic grid data, GIS and the hidden geography of unemployment. Tijdsschrift voor Economische en Sociale Geografie, 22(2), 139-147. Doi: 10.1111/1467-9663.00146.

[40] Sachs, J. \& Warner, A. (1997a). Fundamental Sources of Long-Run Growth. The American Economic Review, 87(2), 184-188. 
[41] Sachs, J. \& Warner, A. (1997b). Natural Resource Abundance and Economic Growth. Center for International Development and Harward Institute for International Development. Cambridge: Harward University.

[42] Siirilä S., Hautamäki L., Kuitunen J. \& Keski-Petäjä T. (1990). Regional well-being variations in Finland. Fennia, 168(2), 179-200.

[43] Stedman, R., Parkins, J. \& Beckley, T. (2004). Resource Dependence and Community Well-Being in Rural Canada. Rural Sociology, 69(2), 213-234. Doi: $10.1526 / 003601104323087589$.

[44] Stedman, R., Parkins, J. \& Beckley, T. (2005). Forest dependence and community wellbeing in rural Canada: variation by forest sector and region. Canadian Journal of Forest Research, 35(1), 215-220. Doi: 10.1139/x04-140.

[45] SuomiCD (2006). Data CD. Helsinki: Statistics Finland.

[46] Terluin, I. and J. Post (2000) (eds). Employment Dynamics in Rural Europe. Wallingford: CABI Publishing.

[47] Tervo, H. (1998). The development of regional unemployment differentials in Finland in the 1990s. Finnish Economic Papers, 11(1), 37-49.

[48] Tervo, H. (2009). Centres and Peripheries in Finland: Granger Causality Tests Using Panel Data. Spatial Economic Analysis, 4(4), 377-390. Doi: 10.1080/17421770903317652.

[49] Tuhkunen, A. (2007). Between location and a sense of place. Acta Universitatis Tamperensis, 1207.

[50] Vaattovaara M. (1998). Pääkaupunkiseudun sosiaalinen erilaistuminen: ympäristö ja alueellisuus. Helsinki: City of Helsinki Urban Facts Research Series.

[51] Van de Ven, P., Kazemier B. \& Keuning S. (1999). Measuring Well-being with an Integrated System if Economic and Social Accounts. Voorburg/Heerlen: Statistics Netherlands.

[52] Zhang, D., Lee, H., Wang, C., Li, B., Zhang J., Pei, Q. \& Chen, J. (2011). Climate change and large-scale human population collapses in the pre-industrial era. Global Ecology and Biogeography, 20(4), 520-531. Doi: 10.1111/j.1466-8238.2010.00625.x. 